J. Perinat. Med. 8 (1980) 100

\section{Practical experiences in the prevention of prematurity using THALHAMMER's score}

\author{
R. Pavelka, P. Riss, O. Parschalk, E. Reinold
}

1st Dept. of Obstet. and Gynecology, University of Vienna

(Head: Prof. E. GITSCH).

\section{Introduction}

The etiology of prematurity exhibits many heterogenous factors and circumstances before and during pregnancy. Several authors developed systems to assess the risk of a pre-term delivery. These scoring systems have been become necessary, because up to 30 factors have been considered to have an influence on prematurity. The purpose has been always to select high risk patients who require intensive prenatal care in order to eliminate or to compensate such risk factors. In particular the significance of one single factor is often found to be very different from another one. Thus it has been essential to characterize each factor with a certain number of risk points. On the other hand the combination of some circumstances may magnify or diminish the calculated risk, which a mere addition of points does not represent.

PAPIERNIK reported 1969 [14] his coefficient for a risk of a premature delivery based on results of own studies and literature. In a recent report [15] he could show a decrease of prematurity rate (without twins) in the area of ClAMART from $10.1 \%$ (1973) to $3.9 \%$ (1977), assumably due to efforts of recognization of pre-term risk, followed by adequate therapeutic measures. SALING published 1972 his prematurity-dysmaturity-prevention program (PDP-program) [20] which is based mainly on present and previous obstetrical characteristics; social factors are listed

\section{Curriculum vitae}

ROLAND PAVELKA was born 1944 in Baden near Vienna, Austria. He studied and obtained. his MD at Vienna University (1970). During his medical studies he worked at the Institute for Anatomy, and after graduating also at the Institute for Electromicroscopy and Micromorphology, publishing anatomical and ultrastructural papers

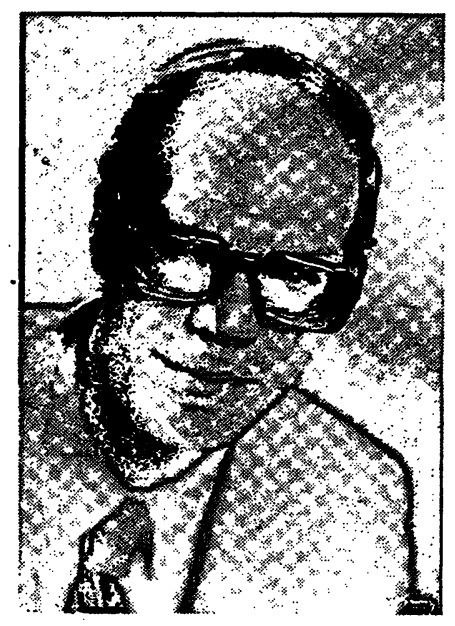

(e.g. on ovocytes). - Since 1973 he has been on the staff of the 1st department of Obstetrics and Gynecology, University of Vienna. His main fields of interest are perinatology (prematurity, behavioral psychosomatic preparation for childbirth, iron stores in pregnancy), gynecologic endocrinology, ultrastructure of the placenta. Respective papers have been published or are in print.

under variable factors. This useful and valuable program, and the resulting experiences with it [6] induced us to establish a special outpatient clinic for intensive prenatal care on the model of SALING's PDP-outpatient clinic. Our experiences have been reported in previous papers $[9,16]$. Although it was possible to lower the prematurity rate [16], this special outpatient clinic concentrates on high risk patients in our hospital, so that it will be doubtful whether a further decrease of pre-term deliveries in the hospital's statistics will be within reach. Also FEDRICK [4] 
presented in 1976 an antenatal scoring system for identification of women at high risk of preterm birth, based on an analysis of 283 singleton pregnancies [3].

Without diminishing the value of SALING's score, we wanted to get experience with another prematurity score which has been composed by THALHAMMER [21, 22], an author who arrived at his results firstly by analyzing the gestations of the neonates of the Vienna University Children's Hospital therefore mainly deliveries of the two University hospitals for Obstetrics and Gynecology. Thus one advantage of this score is that it fits our local area. Furthermore the score pays special regard to pregnant women coming from the lower social class. This concerns many foreign workers who have problems in attending adequate prenatal care mostly for reasons of ignorance of the possible dangers. At last the score does not list only single risk factors, but also combinations of two factors, resulting in an own total of risk points. Our experiences with THALHAMMER's score, the performed therapeutic measures, the outcome of pregnancies of a intensive care group and a comparison group will be presented.

\section{Selection of patients and methods}

In this prospective study all pregnant women were included, who came for their registration for delivery to the outpatient clinic of the hospital. Factors considered by the score recommended by THALHAMMER [21, 22] as a risk for preterm delivery were assessed. If the total exceeded $\mathbf{3 0}$ risk points these women were labelled as a high risk group. It is emphasized that the total of risk points has been relevant for this attribution - not the single factors. According to THALHAMMER therefore twin pregnancies ( $=62$ risk points!) are also found in this collective. Our tables show them separately in parenthesis. All those women were invited to a regular care by our intensive prenatal outpatient clinic. Private patients who did not come into the general outpatient clinic are not included in this study.

During the year 1977 and the first quarter of 1978 162 gravidae were referred by the general out- patient clinic to the intensive prenatal care unit (7.1\% of all pregnant women at that time). 121 patients accepted our invitation to this intensive prenatal care which is always performed by the same team of obstetricians and nurses at a particular time. This care consists of regular clinical including vaginal - hormonal, ultrasonic examinations at short intervals, generally every two weeks, and at the end of the pregnancy of cardiotocographic monitoring [17]; in selected cases also of placental perfusion measurements [10]. 41 patients refused this invitation for intensive care, but they were examined by their practitioners or gynecologists mostly at least four times during a pregnancy of a minimal duration of 35 weeks, according to the minimum of legal recommendations in Austria. The causes for refusal were different, for instance being unwilling to come to the hospital's outpatient clinic over a long local distance, or due to personal family problems.

Due to this situation we were able to divide the entire high risk group into two collectives of patients with a similar position: One collective the intensive care group (i.-c.-group) - consists of 121 patients, the other collective - our comparison group (comp.-group) - consists of 41 patients. Thus it is evidently impossible to randomize both groups statistically for obvious, particularly ethic reasons. The course and outcome of the pregnancies of both groups were analyzed.

\section{Results}

The distribution of the number of risk points presented by the pregnant women coming the first time to the general prenatal care unit, was similar (Tab. I). The arithmetical mean of risk points in the i.-c.-group is 62.3, and in the comp.-group 63. The numbers of previous pregnancies and previous births, as shown in means and ranges in Tab. II are of interest. Also the fact of a first pregnancy is important because there is no information about previous gestations. Though the percentage of primigravidae is fairly equal the numbers of primiparae differ clearly. The times of first examination of the patients in the i.-c.- 
Tab. I. Distribution of risk points at the time of first examination in the general prenatal outpatient clinic, numbers of patients.

\begin{tabular}{ccc}
\hline risk points & $\begin{array}{l}\text { intensive care } \\
\text { group }(\mathrm{n}=121)\end{array}$ & $\begin{array}{l}\text { comparison } \\
\text { group }(\mathrm{n}=41)\end{array}$ \\
\hline$\leqslant 30$ & 5 & 1 \\
$31-50$ & $33(27 \%)$ & $13(31 \%)$ \\
$51-60$ & $20(17 \%)$ & $8(20 \%)$ \\
$61-70$ & $21(17 \%)$ & $6(15 \%)$ \\
$71-80$ & $21(17 \%)$ & $3(7 \%)$ \\
$81-90$ & $14(12 \%)$ & $4(10 \%)$ \\
$91-100$ & 3 & 0 \\
$>100$ & 4 & 6 \\
total & $121(100 \%)$ & $41(100 \%)$ \\
\hline
\end{tabular}

Tab. II. Datas of obstetrical history of both groups.

\begin{tabular}{lll}
\hline & $\begin{array}{l}\text { intensive care } \\
\text { group }(\mathrm{n}=121)\end{array}$ & $\begin{array}{l}\text { comparison } \\
\text { group }(\mathrm{n}=41)\end{array}$ \\
\hline $\begin{array}{l}\text { previous } \\
\text { pregnancies } \\
\text { (mean, range) }\end{array}$ & $2.54(0-14)$ & $2.6(0-9)$ \\
$\begin{array}{l}\text { previous } \\
\text { deliveries } \\
\text { (mean, range) }\end{array}$ & $0.8(0-4)$ & $1.0(0-4)$ \\
$\begin{array}{l}\text { primigravidae } \\
\text { (numbers) }\end{array}$ & $16(13 \%)$ & $4(10 \%)$ \\
$\begin{array}{l}\text { primiparae } \\
\text { (numbers) }\end{array}$ & $53(44 \%)$ & $10(24 \%)$ \\
\hline
\end{tabular}

Tab. III. Weeks of first examination and number of patients in the special intensive prenatal care unit.

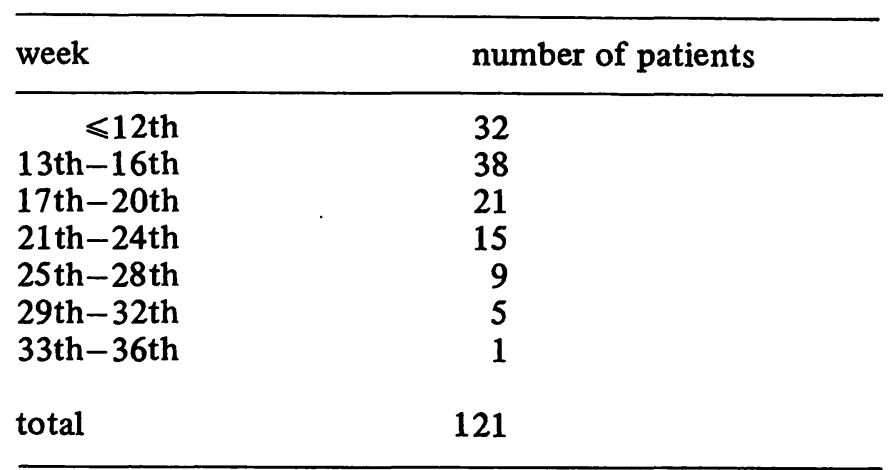

group performed in the described intensive prenatal outpatient clinic are shown in Tab. III. $75 \%$ of those patients exceeded the score limit until the 20th week of gestation which is important for consecutive early treatment. The highest score was found in $72 \%$ of the patients until the 24th week. 6 pregnant women did not reach the limit of 30 points at the first examination in the general outpatient clinic.

\subsection{Diagnostic findings and therapeutic pro- cedures}

The described examinations were performed in the i.-c.-group 9.36 times $\pm 7.6(\bar{x} \pm S D)$. This surprisingly low frequence is due to shortness of gestation in some patients or due to commencing late with the intensive prenatal care as shown in Tab. III.

The pathologic findings concerning prematurity ensued by adequate treatment may be classified into three main groups Tab. IV:

a) pre-term contractions of the uterus, effecting a change of the cervical palpation findings which led us to administer tocolytic drugs to outpatients.

b) Cervical incompetence diagnosed by usual vaginal examination or by a history of late spontaneous abortions. Our policy was surgical correction (SHIRODKAR mostly in the modification of MCDONALD [12].

c) These and other pathologic findings forced us to admit the gravidae to the hospital. These conditions were severe EPH-gestosis, suspicion of severe placental insufficiency, urinary infections associated with fever, rupture of the membranes and/or premature labor.

Tab. IV. Performed treatment in high risk groups.

\begin{tabular}{lll}
\hline & $\begin{array}{l}\text { intensive care } \\
\text { group }(\mathrm{n}=121)\end{array}$ & $\begin{array}{l}\text { comparison } \\
\text { group (n=41) }\end{array}$ \\
\hline $\begin{array}{l}\text { tocolytics } \\
\text { (only outpatients) }\end{array}$ & $74(61 \%)$ & $3(7 \%)$ \\
$\begin{array}{l}\text { corrections of } \\
\text { cervical incompetence } \\
\text { (SHIRODKAR) }\end{array}$ & $63(52 \%)$ & $5(12 \%)$ \\
$\begin{array}{l}\text { recurrent correction } \\
\text { of cervical incompetence }\end{array}$ & $6(5 \%)$ & 1 \\
$\begin{array}{l}\text { admittance to the } \\
\text { hospital } \\
\text { (without surgery) }\end{array}$ & $35(29 \%)$ & $4(10 \%)$ \\
\hline
\end{tabular}


Tab. V. Numbers of patients and weeks in which correction of cervical incompetence was performed.

\begin{tabular}{rcl}
\hline week & $\begin{array}{l}\text { intensive care } \\
\text { group }(n=121)\end{array}$ & $\begin{array}{l}\text { comparison } \\
\text { group }(n=41)\end{array}$ \\
\hline <14th & 7 & 0 \\
15 th-18th & 16 & 0 \\
19 th-25th & 26 & 1 \\
26 th-28th & 9 & 3 \\
$>28$ th & 5 & 1 \\
totals & $63(52 \%)$ & $5(12 \%)$ \\
\hline
\end{tabular}

In the i.-c.-group much more treatment was possible than in the other group in which patients came only into the hospital in case of complaints. In these cases the treatment was on the same principles. This fact is clarified in Tab. $\mathrm{V}$ in the comp.group corrections of cervical incompetence were performed only in few cases and mostly after the 25 th gestational week. Also recurrent corrections during the same pregnancy were necessary in 5 patients of the i.-c.-group (Tab. IV). Signs of EPH-gestosis were observed in $13(11 \%)$ patients of the i.-c.-group and in $3(7 \%)$ of the comp.group.

Beside medical problems social circumstances are an etiologic factor for prematurity $[1,9,11,16]$. $86(71 \%)$ of the women in the i.-c.-group were usually working. Only in 15 cases it was necessary to recommend the patient to stop working for the entire duration of gestation (in 9 patients before the 20th week). But 34 (39\% of the above 86 working women) had to be admitted to the hospital for several reasons as described above. Thus more than half of the working women in the i.-c.-group could not work during the whole time of pregnancy until the legal protective limit (in Austria 8 weeks before the expected date of delivery).

\subsection{Outcome of pregnancy}

Only $13 \%$ pregnancies of the i.-c.-group did not reach the 36th week of gestation, in the comp.group it was $29 \%$ (Tab. VI). We assume this gestational age is more important for fetal lung maturity [5] than a classification summarizing all cases
Tab. VI. Weeks and numbers of delivery in high risk groups (number of women with twin pregnancies in parenthesis).

\begin{tabular}{|c|c|c|}
\hline weeks & $\begin{array}{l}\text { intensive care } \\
\text { group }(n=121)\end{array}$ & $\begin{array}{l}\text { comparison } \\
\text { group }(n=41)\end{array}$ \\
\hline $\begin{array}{r}\quad \leqslant 28 \text { th } \\
29 \text { th }-31 \text { th } \\
32 \text { th }-35 \text { th }\end{array}$ & $\begin{array}{l}7 \mathrm{ab} . \\
1 \\
8(1)\end{array}$ & $\begin{array}{l}2 \mathrm{ab} . \\
2 \\
8(2)\end{array}$ \\
\hline $\begin{array}{l}\text { TOTAL } \\
\text { of } \leqslant 36 \text { th }\end{array}$ & $16(13 \%)$ & $12(29 \%)$ \\
\hline $\begin{array}{r}36 \text { th }-40 \text { th } \\
>40 \text { th }\end{array}$ & $\begin{array}{r}96(6) \\
9(1)\end{array}$ & $27(5)$ \\
\hline $\begin{array}{l}\text { TOTAL } \\
\text { of }>36 \text { th }\end{array}$ & $105(87 \%)$ & $29(71 \%)$ \\
\hline
\end{tabular}

from 32 to 37 completed postmenstrual weeks as generally recommended by WHO [27]. However, according to these recommendations (pre-term gestational age is considered as less than $37 \mathrm{com}$ pleted weeks) 21 patients of the i.-c.-group had a premature delivery, and 7 an abortion ( 1 abortion had to be induced for anencephaly), in the comp. group 26 premature deliveries and 2 abortions occurred. Thus the relationship of deliveries of less than 37 weeks appears as $17 \%$ to $63 \%$. Due to the mentioned impossibility to randomization we did not calculate statistical tests. The differences are obvious. An important parameter is the weight of the newborn (Tab. VII). The ratio between underweight infants of both groups is similar. A relationship of the outcome of pregnancy concerning the weights of the newborns to the THALHAMMER's score has been described [2]. In the comp.-group a clear decrease of the mean weights of the infants out of gestations showing more than 75 risk points was observed as compared with gestations showing less than 76 points. The i.-c.-group produced only a slight decrease of mean weights according to increased risk points. However marked lower mean weights in the comp.-Group were seen in all ranges of risk points (Fig. 1).

The treatment in both groups in the delivery room was on the same principles, because there were other obstetricians and midwives, not knowing which group the patient belonged to. Indeed the 
Tab. VII. Weights of newborns in high risk groups (number of twins in parenthesis).

\begin{tabular}{|c|c|c|}
\hline weight (g) & $\begin{array}{l}\text { intensive care } \\
\text { group } \\
(\mathrm{n}=121 \text { women) }\end{array}$ & $\begin{array}{l}\text { comparison } \\
\text { group } \\
(n=41 \text { women })\end{array}$ \\
\hline $\begin{array}{r}<1000 \\
1000-1499 \\
1500-1999 \\
2000-2499\end{array}$ & $\begin{array}{c}7 \mathrm{ab} . \\
2 \\
2(1) \\
18(9)\end{array}$ & $\begin{array}{l}2 \mathrm{ab} . \\
3 \\
11(6) \\
13(9)\end{array}$ \\
\hline $\begin{array}{l}\text { TOTAL } \\
\text { of }<2500\end{array}$ & $\begin{array}{l}29(22 \%) \\
\text { or } 22(17 \%)+7 \mathrm{ab} .\end{array}$ & $\begin{array}{l}29(59 \%) \\
., \operatorname{or} 27(55 \%)+2 \mathrm{ab} .\end{array}$ \\
\hline $\begin{array}{l}2500-2999 \\
3000-3499 \\
3500-3999\end{array}$ & $\begin{array}{l}36(4) \\
48(2) \\
\left.16^{+}\right)\end{array}$ & $\begin{array}{c}11(1) \\
5 \\
4\end{array}$ \\
\hline $\begin{array}{l}\text { TOTAL } \\
\text { of } \geqslant 2500\end{array}$ & $100(78 \%)$ & $20(41 \%)$ \\
\hline OVERALL: & $\begin{array}{l}129(100 \%) \\
\text { or } 122+7 \mathrm{ab} . \\
\text { (8 twin- } \\
\text { pregnancies) }\end{array}$ & $\begin{array}{c}49(100 \%) \\
\text { or } 47+2 \mathrm{ab} . \\
\text { ( } 8 \text { twin- } \\
\text { pregnancies) }\end{array}$ \\
\hline
\end{tabular}

+) 1 infant $>4000$

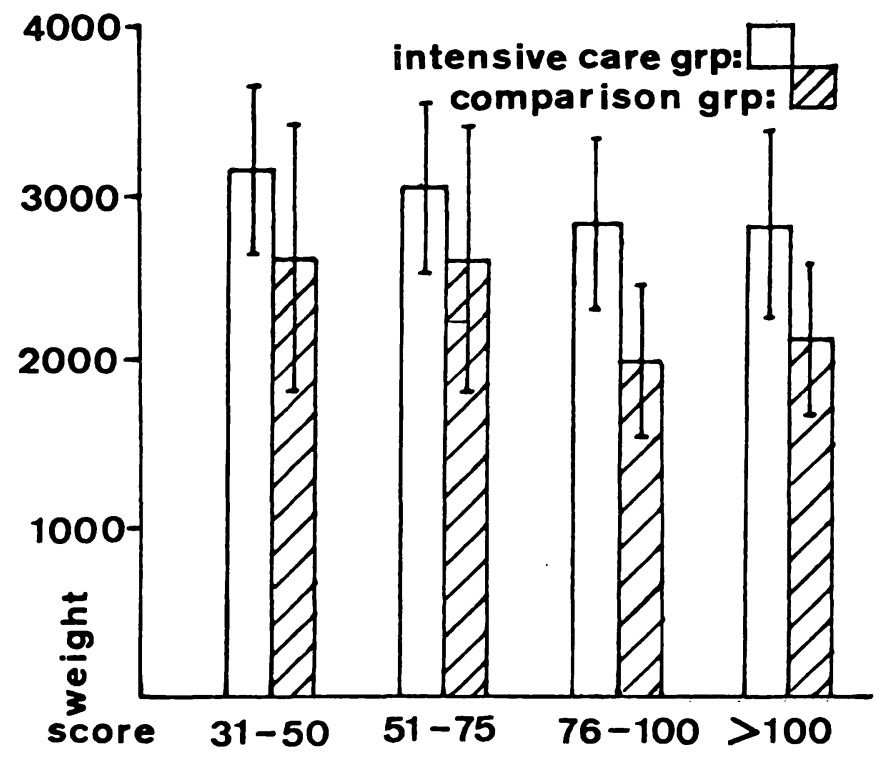

Fig. 1. Weights of the newborne $(\bar{x} \pm$ SD) of both groups in relationship to the THALHAMMER score.

percentage of spontaneous deliveries and of forceps deliveries (vacuum extractions did not occur in this collective) is fairly equal; but an inverse relationship of caesarean section and vaginal breech deliveries appears (Tab. VIII). 11 (9\%) breech presentations were observed in the i.-c.group, and $6(13 \%)$ in the comp.-group. 5 intensive care patients presenting a breech presentation underwent caesarean section. The condition of the newborns assessed by the 1-min APGAR score showed only a slight difference between the two groups (Tab. IX); (mean score in the i.-c.-group: 8.1, in the comp. group: 7.3).

The perinatal mortality in high risk pregnancies is expected to be higher: In the i.c.-group 3 infants out of 122 (2.5\%). (1st: stillbirth, 32th week, $1700 \mathrm{~g}, 43 \mathrm{~cm}$, caesarean section for abruption of the placenta with severe haemorrhage; 2 nd: stillbirth, 32th week, $1300 \mathrm{~g}, 30 \mathrm{~cm}$, premature rupture of membranes, amniotic infection, breech presentation; 3rd: stillbirth, 29th week, $1200 \mathrm{~g}$, $34 \mathrm{~cm}$, abruption of the placenta with haemorrhage.

In the comp.group 2 infants out of 47 (4.2\%). (1st: 32 th week, $1690 \mathrm{~g}, 40 \mathrm{~cm}$, Apgar 3 (1 min) - 9 (5 $\mathrm{min})$, prematurity and respirạtory distress syndrome; 2nd: stillbirth, 29th, $1100 \mathrm{~g}, 37 \mathrm{~cm}$, abruption of the placenta, fetal malformations).

Tab. VIII. Kind of delivery and number of newborn in both groups.

\begin{tabular}{lcl}
\hline & $\begin{array}{l}\text { intensive care } \\
\text { group }\end{array}$ & $\begin{array}{l}\text { comparison } \\
\text { group }\end{array}$ \\
\hline spontaneous & $90(74 \%)$ & $35(74 \%)$ \\
forceps & 4 & 4 \\
caesarean section & $22(18 \%)$ & $2(4 \%)$ \\
vaginal breech delivery & $6(5 \%)$ & $6(13 \%)$ \\
total & $122(100 \%)$ & $47(100 \%)$ \\
\hline
\end{tabular}

Tab. IX. APGAR score after $1 \mathrm{~min}$ and number of the newborn in both groups.

\begin{tabular}{lcc}
\hline & $\begin{array}{l}\text { intensive care } \\
\text { group }\end{array}$ & $\begin{array}{l}\text { comparison } \\
\text { group }\end{array}$ \\
\hline $9-10$ & $73(60 \%)$ & $27(57 \%)$ \\
$7-8$ & $32(26 \%)$ & $6(13 \%)$ \\
$4-6$ & $10(8 \%)$ & $7(15 \%)$ \\
$0-3$ & $7(6 \%)$ & $7(15 \%)$ \\
& &. \\
total & $122(100 \%)$ & $47(100 \%)$ \\
\hline
\end{tabular}




\section{Discussion}

The fact that the contribution of prematurity to early perinatal mortality has been reported from $63 \%$ [28] up to $81 \%$ [19] forces us to make all efforts to prevent pre-term deliveries. Because prematurity is associated with many heterogenous etiologic factors of different dignity the importance of systems to assess the risk of prematurity seems to be obvious $[6,14,15,20,21,22]$. According to other authors surgical corrections of cervical incompetence [12] is a main tool to prevent prematurity, and the number of these operations has been increased greately during the last years $[18,25,26]$; just as a history of dilatation of dilatation of the cervix often results in a cervical incompetence [7]. Supporting procedures are administration of tocolytic drugs to a high number of outpatients too.

The fact that a clear relationship of high risk points and low mean birth weights in the i.-c.group nearly disappeared, although this ratio was found in the comp.-group, as described in THALHAMMER's score [2], may be regarded as a success of our efforts in intensive prenatal care. One purpose of the intensive prenatal care unit was to comprise more patients coming from lower social classes. Although these pregnant women have been described as uninformed about medical care in pregnancy $[13,23]$, and mothers of premature infants have been reported to come less often to prenatal care [15], we got hold of an increasing number of pregnant women from low social state during the last years. The percentage of the lowest social class could be increased from $16 \%$ in the years 1975 and 1976 (at that time we used the prematurity-dysmaturity-prevention score recommended by SALING $[6,16,20]$ up to $37 \%$ in 1977.

The distribution of social classes of the comp.group shows a focal point in the lowest class (i.g. IV) (Tab. X). So the several combinations of risk points concerning this class seem to us an advantage of THALHAMMER's score - in contrast to SALING's score $[6,20]$, but renal diseases are absent, although a relationship between urinary infections and premature labors has been described [8]. In our collective urinary infections screened
Tab. X. Social classes and number of patients in both groups.

\begin{tabular}{lll}
\hline social classes & $\begin{array}{l}\text { intensive } \\
\text { care } \\
\text { group }\end{array}$ & $\begin{array}{l}\text { comparison } \\
\text { group }\end{array}$ \\
\hline $\begin{array}{l}\text { I (university graduates or } \\
\text { husbands in leading } \\
\text { positions) }\end{array}$ & $4(3 \%)$ & 0 \\
$\begin{array}{l}\text { II ("white collar workers", } \\
\text { merchants) }\end{array}$ & $16(13 \%)$ & $2(5 \%)$ \\
$\begin{array}{l}\text { III (trained workmen, } \\
\text { craftsmen, clerks) }\end{array}$ & $59(49 \%)$ & $14(34 \%)$ \\
$\begin{array}{l}\text { IV (unskilled workers, } \\
\text { often foreign workers) }\end{array}$ & $42(35 \%)$ & $25(61 \%)$ \\
\begin{tabular}{l} 
total \\
\hline
\end{tabular} & $121(100 \%)$ & $41(100 \%)$ \\
\hline
\end{tabular}

by positive findings of urinary nitrites and proved by bacterial culture [24] were found in 7 cases of the i.-c.-group, and in 5 cases of the comp.-group.

Generally THALHAMMER's score is able to select high risk patients at an early time of pregnancy usually before the 24th week, often even before the 20th, and earlier, which is important for early consecutive treatment, if necessary. The sometimes changing amounts of the score during pregnancy are found to be less effective.

In conclusion it seems possible to lower an expected high rate of pre-term deliveries significantly until a certain degree in a high risk group-assessed by a predicting score - by early and frequent simple clinical prenatal examinations, additional laboratory findings and tests, associated with surgical and tocolytic procedures, and by supportive measures in the social environment of the pregnant woman. However an effect of such diagnostic and therapeutic programs has been lower in the hospital's statistics than expected (since 1974 SALING's score, percentage of $<2500 \mathrm{~g}$ infants: 1974: 9,4\%, 1975: 11,5\%, 1976: 8,2\%; since 1977 THALHAMMER's score: $1977: 10,4 \%, 1978$ : $9,6 \%)$. A concentration of pathologic cases, and emergency cases without previous registration and examination in the clinic might be responsible for these figures. But such an identification as a highrisk patient and the special prenatal care will have a remarkable advantage for the individual woman. 


\section{Summary}

According to THALHAMMER's predicting score for prematurity high risk gravidae were collected in a prospective study in a time limited period $(n=162)$. From these a group of 121 women (intensive care group, i.-c.-group) was controlled by an intensive prenatal care staff, a group of 41 (comparison group, comp.-group) refused an intensive care. The initial situation of both groups was very similar (mean amount of risk points: 62.3 and 63). $75 \%$ of the patients of the i.-c.-group exceeded the score limit of 30 points until the 20th gestational week. In the i.-c.-group it was possible to perform much more required treatment (in brackets the number of the comp.-group): Cerclage of the cervix in $52 \%(12 \%)$, tocolytics to outpatients in $61 \%(7 \%)$, admittance to the hospital without surgery in $29 \%(10 \%)$. Only in $12 \%$ in the i.-c.-group was it necessary to recommend the patient to stop working professionally for the whole duration of pregnancy. These therapeutic efforts resulted in the outcome of pregnancy: pre-term deliveries (< completed 37 gestational weeks) $17 \%$ compared to $63 \%$, or defined by low birth weight $(<2500 \mathrm{~g}) 17 \%$ to $55 \%)$. A relationship of the mean weights of the infants to an amount of less or more than 75 risk points was observed: in the comp.group a marked decrease of weight in pregnancies showing more than 75 points, whilst in the i.-c.-group this difference was minimal. The conditions of the newborns estimated by APGAR score after 1 minute showed only slight differences: mean score in the i.-c.-group 8.1, and in the comp.group 7.3. THALHAMMER's score is able to select prematurity high risk patients at an early time of pregnancy in most cases before the 24th week, often even before the 20th and earlier, which is important for early consecutive treatment, if necessary. The occasional changing amounts of the score during pregnance are found to be less effective. In conclusion it seems to be possible to lower an expected high rate of pre-term deliveries until a certain degree in a high risk group - assessed by an predicting score - by early and frequent simple clinical prenatal examinations, additional laboratory findings and tests, associated with surgical and tocolytic procedures, and by supportive measures in the social environment of the pregnant women.

Keywords: Prematurity, prematurity-score, prevention of prematurity.

\section{Zusammenfassung}

Praktische Erfahrungen in der Verhütung der Frühgeburtlichkeit unter Anwendung des Punkteschemas von THALHAMMER

Von THALHAMmer wurde ein Punkteschema zur Erkennung frühgeburtsgefährdeter Schwangerer angegeben, wobei ab 30 Punkten ein Risiko angenommen wird. In einer zeitlich begrenzten Periode wurden jene Schwangeren $(n=162)$ erfaßt und sie eingeladen ihre Schwangerschaft in einer eigenen Sprechstunde der Klinik intensiv überwachen zu lassen. 121 Frauen folgten dieser Einladung (intensiv betreute Gruppe, i.-b.-Gruppe); 41 (Vergleichsgruppe, Vgl. Gruppe) konnten oder wollten dieser Einladung zu einer intensiven Betreuung nicht nachkommen. Die Ausgangssituation beider Gruppen war ähnlich (Durchschnittszahl der Risikopunkte: 62.3 und 63). 75\% der Patientinnen der i.-b.-Gruppe überschritten die Grenze des Risikoschemas (30 Punkte) bereits ab der 20zigsten Schwangerschaftswoche. Bei der i.-b.-Gruppe konnte wesentlich mehr erforderliche Therapie durchgefuhrt werden (die Zahlen der Vgl.-Gruppe in Klammer): Cervixcerclage bei $52 \%(12 \%)$, ambulante Verordnung von Tokolytika bei $61 \%(7 \%)$, stationäre Aufnahme (ohne Cerclagen) $29 \%(10 \%)$. Nur in $12 \%$ der i.-b.-Gruppe war eine Empfehlung zu einer Arbeitsfreistellung für die Dauer der gesamten Schwangerschaft erforderlich. Die therapeutischen Anstrengungen wirkten sich auch auf den Schwangerschaftsausgang aus: Frühgeburten $(<$ vollendete 37 Schwangerschaftswochen) erfolgten in $17 \%$ (gegenüber 63\%) der Fälle oder bei einer Definition durch niedriges Geburtsgewicht $(<2500 \mathrm{~g})$ on $17 \%$ verglichen mit $55 \%$. Eine Beziehung zwischen dem Durchschnitt der Geburtsgewichte und der Höhe der Risikopunkte (über oder unter 75 Punkten) wurde beobachtet: Schwangerschaften aus der Vgl.-Gruppe mit über 75 Risikopunkten zeigten einen deutlichen $A$ bfall des durchschnittlichen Kindesgewichtes, hingegen war dieser Unterschied bei der i.-b.-Gruppe minimal. Der Zustand der Neugeborenen - beurteilt nach APGAR nach 1 Minute - zeigte nur geringe Unterschiede: Durchschnittswert in der i.-b.Gruppe 8,1 und in der Vgl.-Gruppe ${ }^{\circ} 7,3$.

THALHAMMER's Punktschema ermöglicht frühgeburtsgefährdete Schwangere frühzeitig, meist vor der 24 . Woche, oft sogar vor der 20. Woche, zu erfassen. Es kann dadurch frühzeitig eine genaue Überwachung der Risikoschwangerschaft und falls erforderlich eine entsprechende Therapie durchgeführt werden. Eine im Verlauf der Schwangerschaft wechselnde. Summe von Risikopunkten zeigte wenig Auswirkung.

Aus den Ergebnissen kann geschlossen werden, daß es möglich ist, eine mittels Punkteschema erwartete hohe Zahl von Frühgeburten (innerhalb einer Risikogruppe) erheblich zu verringern, und zwar durch frühzeitige, regelmäßige klinische und zusätzliche Laboruntersuchungen, sowie durch chirurgische (Cervixcerclage) und tokolytische Maßnahmen (letztere auch bèi ambulanten Patientinnen). Soziale Maßnahmen wie Arbeitsfreistellung können die medizinischen Anstrengungen unterstïtzen. 


\section{Résumé}

Experiences pratiques dans la prévention de la prématurité à l'aide du score de THALHAMMER

THALHAMMER a publié un schéma de points pour le dépistage des grossesses menacées d'accouchement prématuré, un tel risque pouvant être présumé à partir de 30 points. Pendant une période déterminée les femmes enceintes $(n=162)$ ont été portées sur une liste et invitées à subir des examens intensifs dans une consultation spéciale de l'hôpital. 121 ont accepté (groupe de surveillance intensive: i.-b.-Gruppe); 41 (groupe de comparaison: Vgl.-Gruppe) n'ont pas pu ou voulu se soumettre à ces soins intensifs. La situation de départ a été identique pour les deux groupes (moyenne des points de risque: 62,3 et 63 ). $75 \%$ des parturientes du groupe de surveillance intensive ont dépassé la limite du schéma de risque (30 points) dès la 20 ème semaine de grossesse. Il a été possible d'appliquer beaucoup plus la thérapeutique nécessaire dans le groupe de surveillance intensive (les nombres relatifs au groupe de comaparaison figurent entre parenthèses): Cerclage du col de l'utérus chez $52 \%$ des parturientes (12\%), prescription ambulatoire de tocolytiques chez $61 \%(7 \%)$, hospitalisation (sans cerclage) pour $29 \%(10 \%)$. Un arrêt de travail pour toute la durée de la grossesse n'a dû être prescrite que pour $12 \%$ du groupe de surveillance intensive. Les efforts thérapeutiques ont influencé l'issue des grossesses: Accouchements prématurés ( $<37$ ème semaine de grossesse accomplie) dans $17 \%$ des cas (contre $63 \%$ ) ou, lorsque définis par un poids de naissance inférieur à la norme
( $<2500 \mathrm{~g}$ ) dans $17 \%$ (contre $55 \%$ ). On a pu observer un rapport entre la moyenne des poids de naissance et la somme des points de risque (supérieure ou inférieure à 75 points): Les grossesses du groupe de comparaison avec plus de 75 points de risque montrent une baisse très nette de la moyenne des poins de naissance, alors que cette différence est restée insignifiante dans le groupe de surveillance intensive. L'état des nouveaux-nés jugé d'après le score APGAR après $1 \mathrm{~min}$. n'a révélé qu'une faible divergence: moyenne de 8,1 pour le groupe de surveillance intensive et de 7,3 pour le groupe de comparaison.

Le schéma de THALHAMMER permet d'enregistrer les grossesses menacées d'accouchement prématuré dans une phase précoce, le plus souvent avant la 24ème semaine et même souvent avant la 20ème semaine. Ceci permet à son tour d'entreprendre très tôt une surveillance précise de la grossesse à risque et, au besoin, la thérapeutique conforme. Une somme des points sans grand effet.

Les résultats acquis permettent de conclure qu'il est possible de faire baisser considérablement un ombre élevé d'accouchements prématurés (à l'intérieur d'un groupe de risque), escompté par l'in termédiaire du schéma de points, et cela par des examens cliniques et de laboratoire supplémentaires, précoces et réguliers, ainsi que par des mesures chirurgicales (cerclage du col de l'utérus) et tocolytiques (ces dernières pouvant être ambulatoires). Des mesures sociales telles que l'arrêt de travail peuvent soutenir les sfforts médicaux.

Mots-clés: Accouchement prématuré, prévention des accouchements prématurés, score des accouchements prématurés.

\section{Bibliography}

[1] AKKERMANN, S., J. TÖWE, M. VOIGT: Über die Beziehung zwischen Frühgeburt und sozialem Milieu. Z. Ges. Hy. 22 (1976) 548

[2] CORADELLO, H.: A score to predict risk of underweight birth offers also information about degree of postnatal disturbances and prenatal care quality. THALHAMMER, O., A. POLLAK (eds.): Abstracts. 6th European Congress of Perinatal Medicine. Vienna, 1978

[3] FEDRICK, J., A. B. M. ANDERSON: Factors associated with spontaneous pre-term birth. Brit. J. Obstet. Gynaec. 83 (1976) 342

[4] FEDRICK, J.: Antenatal identification of women at high risk of spontaneous pre-term birth. Brit. J. Obstet. Gynaec. 83 (1976) 351

[5] FROSOLONO, M. F., J. F. ROUX: Surface-active material in human amniotic fluid. Am. J. Obstet. Gynecol. 130 (1978) 562

[6] GIFFEI, J. M., E. SALING: First results and experiences with our prematurity and dy smaturity prevention program (PDP-program). J. Perinat. Med. 2 (1974) 45

[7] GRỨNBERGER, W., P. RISS: Isthmozervikale Insuffizienz nach vorangegangener Zervixdilatation und Kürettage. Wien. med. Wschr. 129 (1979) 390
[8] HENDERSON, M., W. A. REINKE: The relationship between bacteriuria and prematurity. In: KASS, E. H.: Progress in pyelonephritis, 28. Philadelphia, Davis, 1965

[9] KUCERA, H., R. PAVELKA, B. RUDELSTORFER, E. REINOLD: Einfluß sozialer Faktoren auf die Ergebnisse eines gezielten Frühgeburtenprogramms. Wien. klin. Wschr. 89 (1977) 307

[10] LEODOLTER, S.: Neue Gesichtspunkte zur Erfassung und Behandlung der Plazentainsuffizienz. Wien. klin. Wschr. 89 (1977) Suppl. 70

[11] MAU, G., P. NETTER: Die Bedeutung sozioökonomischer Faktoren für den Schwangerschaftsausgang. Gynäkologe 10 (1977) 41

[12] MCDONALD, J. A.: Suture of the cervix for inevitable miscarriage. J. Obstet. Gynec. Brit. Emp. 64 (1957) 346

[13] MCKINLEY, J. B.: The late newcomers for antenatal care. Brit. J. prev. soc. Med. 24 (1970) 52

[14] PAPIERNIK-BER KHAUER, E.: Le coefficient de risque d'accouchment prémature. Presse méd. 77 (1969) 793

[15] PAPIERNIK-BER KHAUER, E.: Prévention de la prématurité. Gynäk. Rdsch. 18 (1978) 100, Suppl. 1 
[16] PAVELKA, R., B. RUDELSTORFER, R. SCHMID, E. REINOLD: Prospektive Studie mit einem Prämaturitäts - Dysmaturitäts - Präventions - Programm (PDP-Programm nach SALING) unter Berücksichtigung sozialer Faktoren. Geburtsh. u. Frauenheilk. 38 (1978) 1058

[17] REINOLD, E.: Die Überwachung der gefährdeten Schwangerschaft. Wien. klin. Wschr. 86 (1974) 633

[18] REINOLD, E., G. LACKNER: Frequenzzunahme der Zervixverschlußoperationen. Med. Klin. 70 (1975) 551

[19] RUSH, R. W., D. A. DAVEY: The effect of pre-term delivery on perinatal mortality. Brit. J. Obstet. Gynaec. 85 (1978) 806

[20] SALING, E.: Prämaturitäts- und Dysmaturitäts-Präventionsprogramm (PDP-Programm). Z. Geburtsh. Perinat. 176 (1972) 70

[21] THALHAMMER, O.: Verhütung von Frühgeburtlichkeit und pränataler Dystrophie. Z. Geburtsh. Perinat. 177 (1973) 169

[22] THALHAMMER, O., H. CORADELlO, A.POLLAK, S. SCHEIBENREITER, G. SIMBRUNNER: Prospective and retrospective examination of an easily aapplicable score to predict the probability of pre- mature birth defined by weight. J. Perinat. Med. 4 (1976) 38

[23] TƯCKE, M., H. PRIN̦Z, J. WOKECK: Soziale Schicht und Gesundheitsverhalten während der Schwangerschaft. Münch. med. Wschr. 113 (1975) 341

[24] WAgenbîChleR, P., M. ROTTER: Probleme und Möglichkeiten der bakteriologischen Harndiagnostik bei der Erfassung der asymptomatischen Bacteriurie im Rahmen der routinemäßigen Schwangerenuntersuchung. Wien. klin. Wschr. 81 (1969) 789

[25 ] WAGNER, G., H. SALZER, E. REINOLD: Anamnese und Schwangerschaftsverlauf bei Zervixcerclage. Z. Geburtsh. Perinat. 182 (1978) 68

[26] WIDMAIER, G., H. D. REICHHARDT: Erfahrungen mit einer erweiterten Indikationsstellung zur Zervixcerclage in der Schwangerschaft. Zbl. Gynäk. 95 (1973) 16

[27] WORLD HEALTH ORGANIZATION (WHO): Definitions and recommendations: Off. Rec. Wld. Hlth. Org. 28 (1950) 17, 160 (1967) 11, and annex 18, and $233(1976) 18$

[28] WULF, K. H.: Geburtshilfe heute. Geburtsh. u. Frauenheilk. 37 (1977) 357

Received April 12, 1979. Revised July 30, 1979.Accepted October 30, 1979.
Dr. R. Pavelka

I. Universitätsfrauenklinik Spitalgasse 23

A-1090 Wien, Austria 